\title{
LIFELONG LEARNING EXPECTATIONS OF YOUNG ACADEMICS - ANALYSIS OF POLISH AND HUNGARIAN TECHNICAL UNIVERSITIES
}

\author{
Renata WALCZAK*, Anikó KÁLMÁN** \\ *Warsaw University of Technology, College of Economics and Social Sciences, POLAND \\ e-mail: renata.walczak@pw.edu.pl \\ **Budapest University of Technology and Economics, HUNGARY \\ e-mail: drkalmananiko@gmail.com
}

\begin{abstract}
This article presents a qualitative study of lifelong learning (LLL) requirements of university employees from the Warsaw University of Technology (WUT) and the Budapest University of Technology and Economics (BME). The main aim of the study was to gain understanding of young people expectations and attitudes towards LLL. Aims of the study included: identification of employees' requirements in terms of LLL; identification of education activities and employee perception of university activities. Data for the study were gathered in individual interviews. The same, standardized openended questions were used in both institutions to allow comparison of the results. Interview questions concerned the willingness of participation in LLL, education forms, areas of education and perception of the university. The participants of the interviews were 24 young people from the WUT and BME. Research shows that there are no significant differences between Polish and Hungarian representatives who are eager to learn and have many interests and positive features; however, they have high requirements and expectations. This research will allow to prepare informative and effective LLL universities' strategies.
\end{abstract}

Keywords: young generation, lifelong learning, technical universities.

JEL: A20, I20.

Introduction

Technical universities that want to maintain the quality of research and teaching processes must take care of their staff. A training strategy plays a crucial role; however, the employees' opinion is also very important. Unsatisfied and unwilling employees will not benefit from the training, and the university will incur unnecessary costs without a visible effect. There is a little literature available, which enables to recognize lifelong learning needs and demands of young people.

According to the European Pillar of Social Rights in 20 principles „Everyone has the right to quality and inclusive education, training and life-long learning in order to maintain and acquire skills that enable them to participate fully in society and manage successfully transitions in the labour market" (European Commission, 2018g).

European Union life-long learning formal origins go back to 1970s, when in 1971 the European Council, aware of links between education and the economy, decided to establish the program of further training and continuous education in order to improve workers' competences and develop a system of adult education. Free movement of workers, equivalences of degrees and diplomas, and linking adult training with the formal education system were supposed to be a way to implement the Treaty of Rome to ensure optimum economic development. Vocational training should be combined with general training and concrete practice.

People who update their knowledge may expect better employment and higher wage. In order to implement the above assumptions, lifelong learning policy should be implemented at the level of member states, which were obliged to compensate deficiencies in education of underdeveloped regions and people. It was indispensable that national education policies should be coherent with the community recommendations.

Harmonization assumed, among others, involvement of "great" European universities: their teachers and research workers. The EU policy stated that research 
workers, also university staff, technicians of industry, public services workers, and supervisory staff, need permanent, lifelong learning education (Janne, 1973).

The Lisbon Agenda assumed three interwoven criteria for full employment restoration, social cohesion enhancement, and full access to knowledge and educational systems throughout lifespan.

The 1996 was announced a year of Lifelong Learning; in 2002, Council Resolution of June 27, 2002, on lifelong learning has set the foundations for continuous education and educational policies development.

Among others, the priority was given to "the training, recruitment and updating of teachers and trainers for the development of lifelong learning". Among member states' responsibilities was improving the education and training of teachers and trainers involved in lifelong learning so that they acquire the necessary teaching skills for the knowledge society, thus promoting, among other aims, general access to language learning, access for all to information and communication technologies (ICT), and increased participation in scientific and technical studies (Official Journal of the European Communities, 2002).

In 2006, the Council of the European Union has developed key lifelong learning competencies: "communication in the mother tongue; communication in foreign languages; mathematical competence and basic competences in science and technology; digital competence; learning to learn; social and civic competences; sense of initiative and entrepreneurship; cultural awareness and expression" (European Commission, 2006).

In 2018, because of significant changes in economy, technology, demography, and labor market, new revised set of competences was announced; they were "literacy; languages; mathematics, science and technology; digital; personal, social and learning; civic competence; entrepreneurship, cultural awareness and expression" (Council of the European Union, 2018), which should have been promoted by "providing high-quality education, training and lifelong learning for all; supporting educational staff; promoting a variety of learning approaches and contexts, in a lifelong learning perspective; exploring approaches to assessment and validation of key competences" (European Commission, 2018f; e).

Along with the enlargement of the European Union, lifelong learning activities undertaken by the member states should be comparable. Even though targets set by the European Union are voluntary, national lifelong learning activities are evaluated using common measures (Council of the European Union, 2002)

One of them is adults' (aged 25-64 years) participation in continuous education, which was set to $15 \%$ as the 2020 aim for the European Union; however, in 2017, the EU average achieved 10.8\% (target for 2020 is $15 \%$ ). People with tertiary education were more willing to study: $18.6 \%$ of them have continued learning, $8.8 \%$ people with secondary education have learned after graduation, and only $4.2 \%$ with primary education wanted to participate in lifelong learning (European Commission, 2018b).

In 2016, Poland has reported $3.7 \%$ of adult participation in learning and Hungary reported 6.3\% (Eurostat, 2018), and it was the worst education index, out of all, for both countries (Fig. 1). The structure of continuous learning both in Poland and in Hungary is based on nonformal activities (Fig. 2).

Formal learning is not so popular. Only big companies provide additional possibilities for learning, and its availability is limited. The ratio of formal and informal types of adult education and training also depends on compulsory health and safety courses and similar obligatory training.

In addition, when there is a presence of educational funds, companies are more willing to promote additional learning. Companies provide more formal courses when they do not want to hire older workers. In this case, young staff is trained in order to replace older workers (European Commission, 2018b).

Taking into account the aforementioned European Union requirements, technical universities, in addition to engineering education, must take care of the professionalism of their staff. Young generation, students and young employees, should be provided with current and comprehensive knowledge, which is impossible without constantly improving academic staff. 

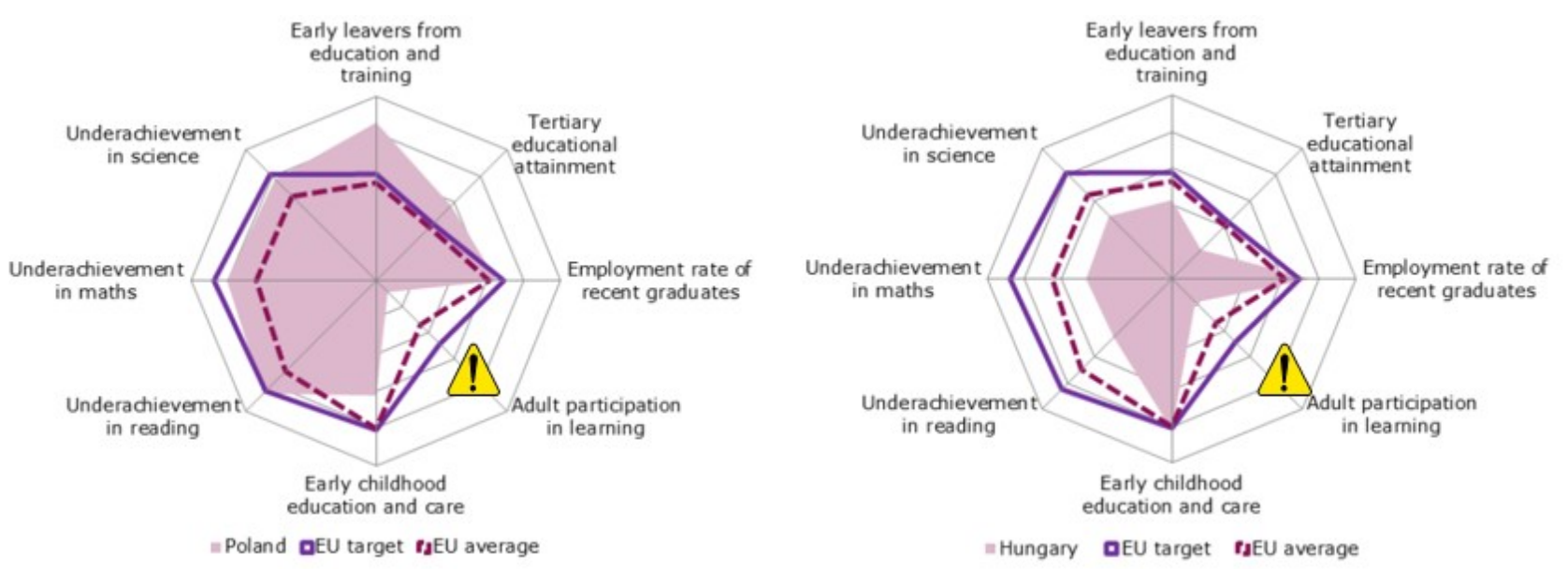

Figure 1. Education performance of Poland and Hungary in relation to the EU targets. Outer rings indicate achievements of the strongest performers and center of the octagon indicates the weakest performers

(Source: European Commission, 2018c; 2018d)

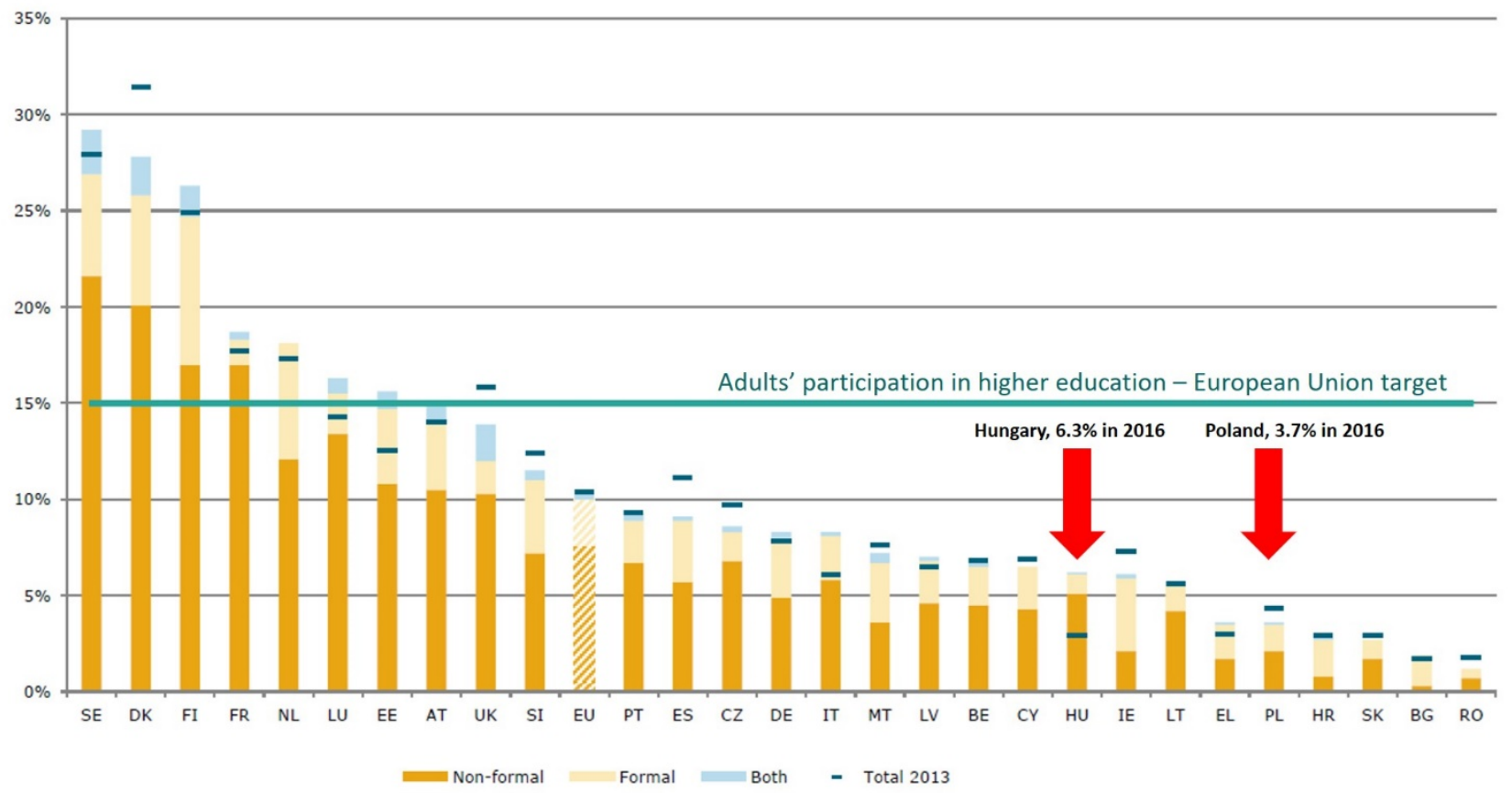

Figure 2. Adults' (age 25-64 years) participation in higher education in the European Union (Source: European Commission, 2018b)

University employees, the selected people, the best of the best, have no problems with learning. They acquire knowledge throughout their lives; however, the learning process should be structured, related to the university strategy and purposeful.

A university training strategy plays a crucial role; nonetheless, the employees' opinion is very important. A researcher and an academic teacher should not be forced to do anything. Unsatisfied and unwilling employees will not benefit from the training, and the university will incur unnecessary costs without a visible effect. Academic staff should learn continuously updating their skills and knowledge. Universities should pay attention to education of young academics.

There is a little literature available, which enables to recognize young people's needs and expectations regarding lifelong learning. Wider research regarding this area is being carried out as a part of the Horizon 2020 project. The Warsaw University of Technology 
(WUT) in Poland, one of the participants, conducts research on generation Z's and generation Y's attitudes. Besides the study being the subject of this article, the research performed by the WUT within H2020 project will be taken into account in drawing conclusions of this analysis.

The aim of the present study was to achieve a holistic understanding of young people's, employees of technical universities, expectations and attitudes towards lifelong learning. Research was carried out at the WUT and Budapest University of Technology and Economics (BME) in Hungary.

To build the case study of the universities' individual interviews with representatives of generations $Y$ and $\mathrm{Z}$ were conducted. The same standardized openended questions were used in both institutions to allow comparison of the results. Research questions concerned the willingness of participation in lifelong learning, education forms, and areas of education.

The participants of the interviews were 37 young people representing both generations and both universities. As a result, the study regarding generation Y's and Z's approach to learning were prepared, which was found important for effective lifelong learning management at the universities.

\section{Background of the Problem}

In 1960s and 1970s of the 20th century in Poland, it was assumed that one should learn at the appropriate age at school. Even postgraduate studies and doctoral studies were not as popular as they are today. People took a job after a period of formal education. They used to work in one profession and in one workplace throughout their whole professional life. Those who studied as adults were considered as lagging far behind the rest of the society (Kobylarek, 2002).

Such concept was criticized by Faure, et al. and a new idea was promoted - life-long education, which would have "produced the kind of complete man the need for whom is increasing with the continually more stringent constraints tearing the individual asunder" and that "creation of the learning society should become a key strategy for facilitating learning throughout life for individuals and societies" (Faure Edgar, Herrera Felipe, Kaddoura AbdulRazzak, Lopes Henri, Petrovsky Arthur V., Rahnema Majid, 1972).

It should be mentioned that work was obligatory in Poland and Hungary during the socialist period. Everything was changed after 1989. Free market, nonobligatory work, and rising unemployment forced people to change their professions. Many trainings and courses, especially managerial ones, were launched. Along with the entry to the European Union, the term "life-long learning" and "life-long education" became fashionable both in both Poland and in Hungary. Now, especially at the universities, "lifelong learning" is widely implemented; however, there is no certainty whether the effects go hand in hand with learners' expectations and whether academics understand what is expected of them.

\subsection{Lifelong learning in Poland and Hungary}

Educational system in Poland was assessed as one of the best as compared to the European Union. Primary, secondary, and higher education performance is very strong; however, vocational education still needs changes. Graduates' skills do not match the demand of the labor market. People who update their knowledge may expect better employment and higher wages. Unfortunately, there is no national adult educational policy in Poland.

So far, only a strategy for introducing lifelong learning has been prepared. As a result, Poland has the worst lifelong learning achievements in the European Union (Figs. 1 and 2) (European Commission, $2018 b$ ). Even though there are some educational programs, for example, "The Human Capital Operational Programme 2007-2013" (European Social Fund, 2013) and "Knowledge, Education, Development Operational Programme 2014-2020," adult participation in learning has gradually declined over the years. In addition, it should be noted that more women than men learn after graduation, and tertiary education graduates predominantly benefit from lifelong learning (Fig. 3). 

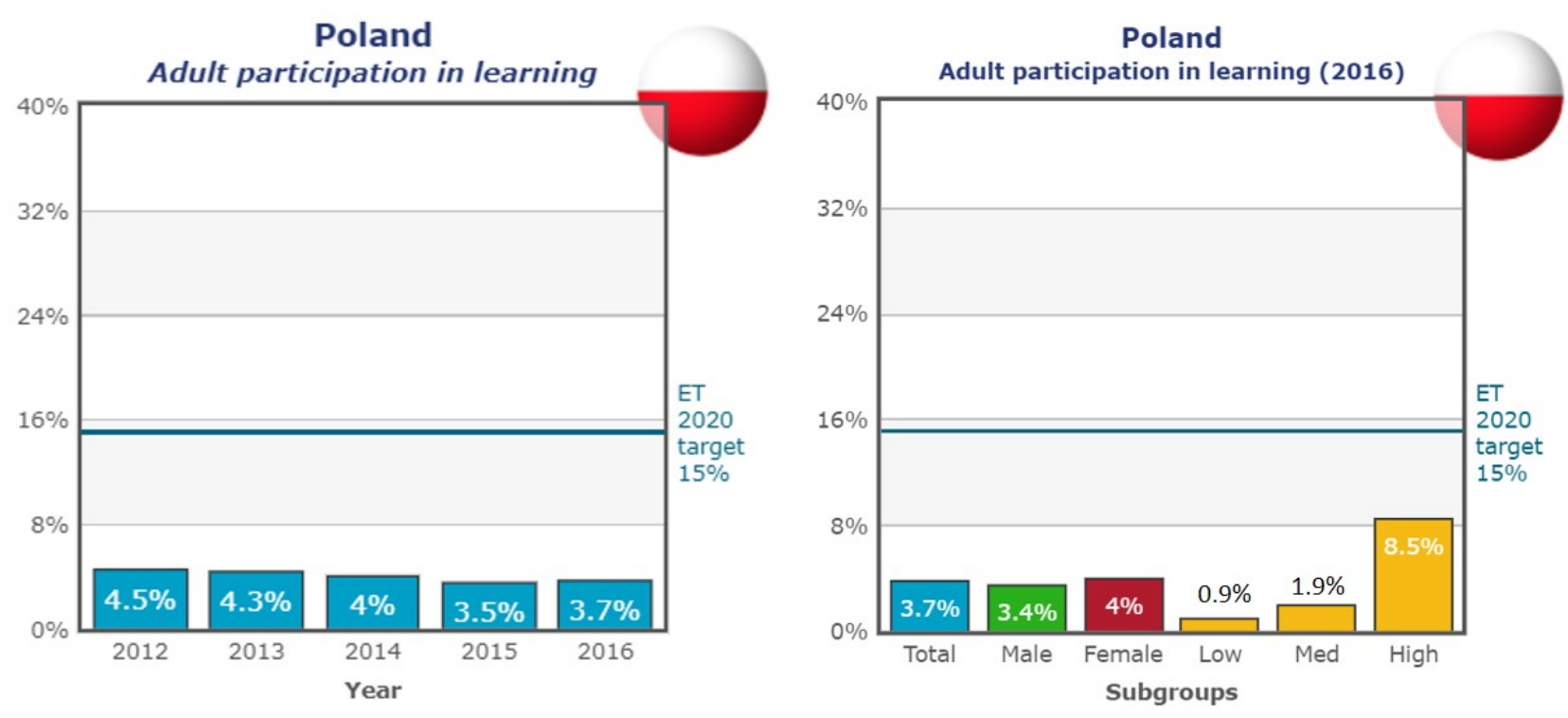

Figure 3. Adult participation in learning in Poland

(Source: European Commission, 2018a)

Citizens are not interested in continuous learning and development, even though it is necessary to keep up with market requirements. Despite of great results in Programme for International Student Assessment evaluation, according to the European Union's Education and Training Monitor 2017, Poland faces a breakdown in adult lifelong education. People do not want to learn. Polish adults have difficulties in reading and counting. The sources of the problem are in the school system, from the very beginning, started from the primary school. Especially, ICT literacy is a particular problem.

The European Commission underlines that the problem stems from lack of lifelong learning policy at the national level and poor engagement of stakeholders. Polish government is about to prepare new law regarding adult education and training; however, it is still in its infancy (European Commission, 2018b).

In Hungary, there are fewer and fewer people possessing the skills required by the economy. This is due to the fact that performance of educational system is not very strong and recruitment for higher education institutions is declining, even though that government spends large funds for learning (5.2\% of GDP (gross domestic product) in 2016, more than EU average, $4.9 \%$, in 2016). In order to finance it, government has set up new tax - "solidarity contribution" - to support central budget for education. Unfortunately, many well-educated people go abroad, especially to Germany and Austria. To fill the gap, adult education has slightly improved; however, it was worse in 2016 (7.1\%) than in 2015 (6.3\%). In 2016, adult participation in learning, $6.3 \%$, was significantly lower than the European average. Just like in Poland, far more women than men learn during their life; also more people with higher education have benefit of lifelong learning (Fig. 4).

Hungarian government pays special attention to lifelong learning. The Act on Adult Education promotes adults' education in order to improve Hungarians' "economic, cultural and technological development." Adults may participate in education (within a school system) and training (outside the school system, for those who have completed formal education). Both forms are a second chance for people who lack qualifications they need. Both models serves as manner to develop vocational and professional qualifications and help unemployed people to get new knowledge and skills (language and digital) (EURYDICE, 2018). 

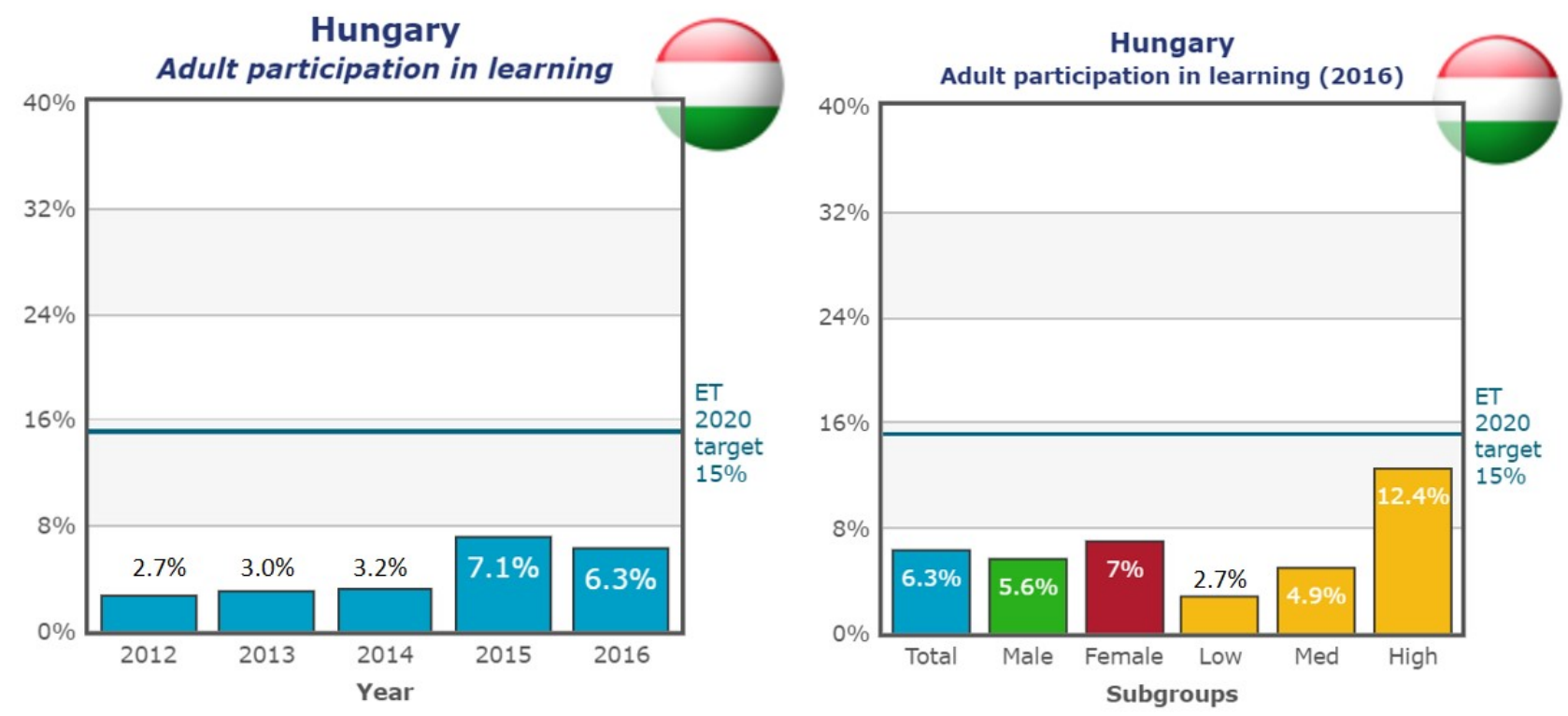

Figure 4. Adult participation in learning in Hungary

(Source: European Commission, 2018a)

Lifelong learning has become indispensable activity both in Poland and in Hungary; the number of tertiary education graduates has increased; however, additional education is still needed. The mismatch between education and occupation is wide in Poland and Hungary. In Poland, more than $35 \%$ of graduates with bachelor's degree do not work in their chosen profession; in Hungary, the same indicator reaches $20 \%$. Accordingly, almost $20 \%$ of graduates with master's degree in Poland and $10 \%$ of those in Hungary cannot find work in their profession. In this case, workforce must get additional training to compensate educational deficiencies (Fig. 5) (European Commission, 2018b).

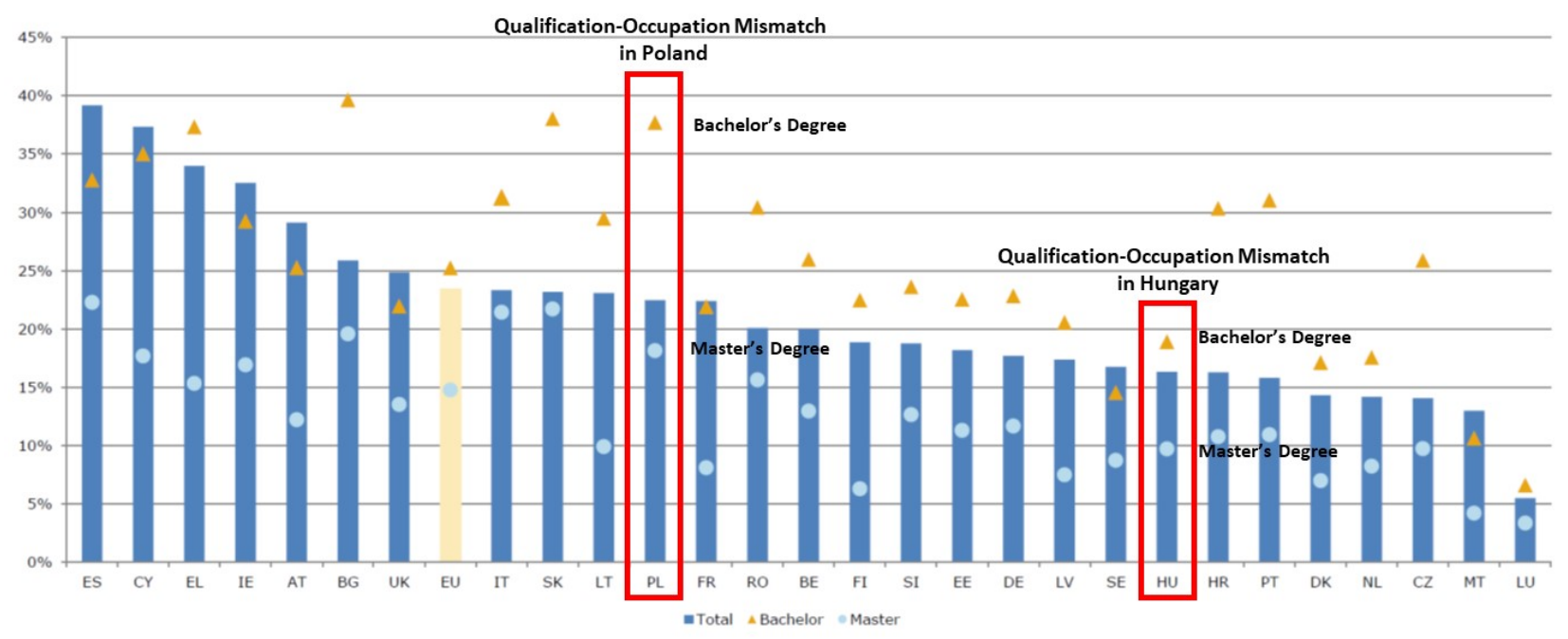

Figure 5. Occupation-chosen profession mismatch in the European Union (Source: European Commission, 2018b)

\subsection{Universities' strategies}

The WUT, the largest technical university in Poland and, according to widely recognized ratings, the best one, the largest in terms of potential, the best in terms of achieved technical results, has the highest prestige among employers who primarily assess the overall level of graduates, their knowledge, skills 
acquired at the university, and their usefulness for the profession. These excellent results depend on the work of thousands of employees and students and the accumulated achievements of many generations of teachers and scholars; however, the university cannot afford to be inactive. The continuing development will ensure keeping the university's current position and enable effective competition with similar universities at home and abroad. In 2011, new 2020 strategy (Warsaw University of Technology, 2011), consistent with the government strategy, has been introduced.

Defined strategic goals have been decomposed into operational goals and, subsequently, to specific actions. The strategy is binding for WUT and authorities of the WUT faculties. All WUT units should operate according to its guidelines. WUT aims to achieve the status of a world-class technical university, developing research, educating students and $\mathrm{PhD}$ students at the highest level, and transferring the results of scientific research to the economy.

Key areas of the strategy are education, scientific research and commercialization of research results, WUT cooperation with the environment, academic community, fixed and intangible assets, and management and finance; however, for the purpose of strategy management, four areas were defined: education, scientific research and commercialization of research results, cooperation of the university with the environment, and organization and management (Fig. 6).

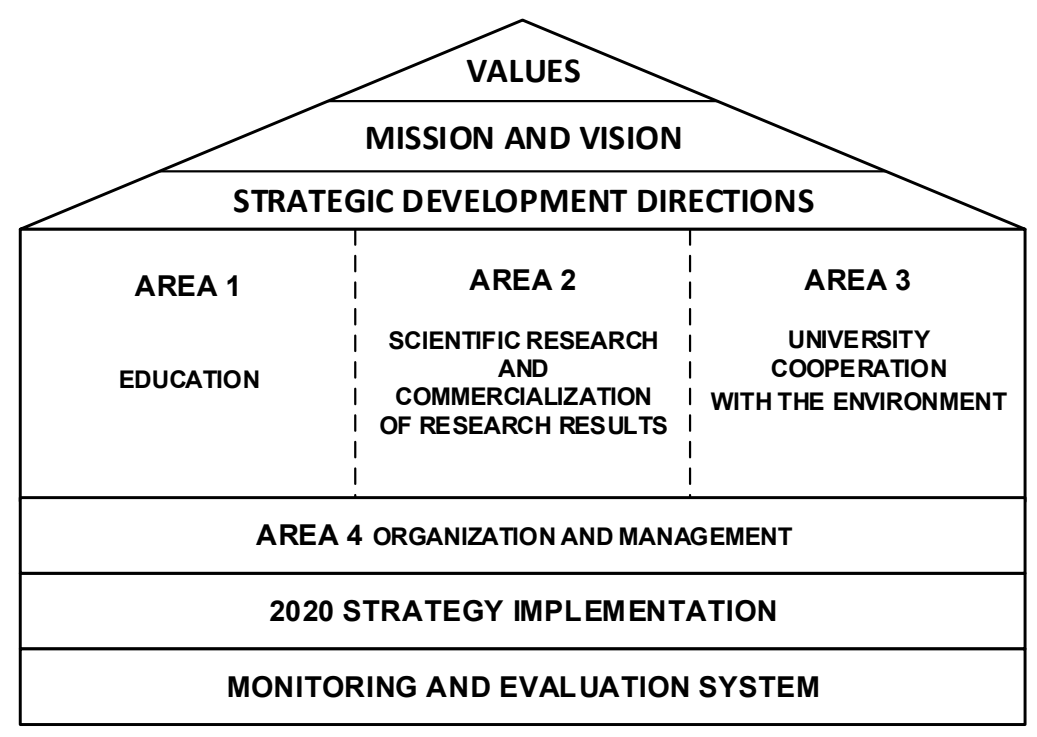

Figure 6. Model of the Warsaw University of Technology's strategy development

(Source: Warsaw University of Technology, 2011)

According to SWOT (strengths, weaknesses, opportunities, threats) analysis, strengths of the WUT, regarding its staff, are high qualification of scholars; their commitment into teaching and research; high international position of some researchers; good cooperation with international researchers; excellent cooperation with the industry; experience in the field of technology transfer and commercialization; large number of doctoral students participating in research projects; significant achievements of students and students' research groups; and significant potential of employees with higher education not being university teachers.
Weaknesses of the WUT are poor preparation of most academic teachers in the field of innovative methods of education and teaching in English; lack of some scholars' experience related to the industry; high average age of academic teachers; small mobility within university and interinstitutional scale; considerable didactic overload; very large diversity in the level of research teams and their activity scientific research with low average activity; low number of yearly doctoral and postdoctoral degrees awarded; decreasing number of doctoral students; insufficient number of engineering and technical employees involved in education and research; a small percentage 
of students involved in research; no policy in university (in 2011) regarding education of talented students; authorities of autonomous faculties did not want to implement unpopular reforms; lack of incentive system for employees; lack of a university remuneration system, consistent with European "standards" rewarding people employed in universities and other research institutions; inefficient employee evaluation system; and lack of project management qualifications, especially related to international projects.

The WUT also notices a number of opportunities, regarding its staff, arising from the environment: increasing society awareness of higher technical education; perception of the WUT as leading technical university and a source of professional personnel; the environmental requirements for cooperation, the prospect of cooperation with various sectors of economy; advantageous national programs (e.g., structural funds, framework programs) for higher education, planned change of the act for higher education, pro-quality ministry financing system; priorities for internationalization.

The WUT authorities are aware of environment threats: expected resistance of staff and students toward improving the quality of education; low attractiveness of academic teacher profession and, as a result, brain drain; lack of tradition of improving academic teacher competencies; low university staff wages and, as a result, necessity to take another jobs; limited demand for research from external stakeholders; lack of conditions that facilitates scholars mobility; unsatisfactory level of funding from the state budget and, as a result, limited possibilities of growth; bad and rigid legal rules and regulations making impossible to conduct rational HR (human relations) policy (Warsaw University of Technology, 2011).

Considering all strengths, weaknesses, opportunities, and threats, the WUT authorities decided to implement new strategy and introduce several actions in order to improve university performance, especially in relation to academic staff. The WUT authorities have pro-reform attitude to staff development. Training department, at the request of the Rector, implements the WUT strategy. Its mission is to provide lifelong learning opportunities for the WUT employ- ees. Their main task is to take care of the professional development of the staff and, in this way, the development of the entire University.

The training department organizes trainings tailored to the current needs of employees, aimed at improving the competences and qualifications of scholars. In 2016, training department has organized 112 trainings for almost 3000 employees. Some trainings were compulsory; however, there were several ones regarding soft and hard skills: motivation, selforganization, team relations, time management, autopresentation IT skills, management, law, and finance (WUT, 2018c).

New entity of the WUT, Centre for Innovation and Technology Transfer Management (CI\&TTM), was created to develop academics, develop their innovative entrepreneurship, provide training, build culture of innovation, boost technology transfer, and organize conferences and seminars. CI\&TTM is equipped in 12 different laboratories and studios: Social Research Lab, Non-technological Innovations Lab, Data Processing and Analyses Lab, Project Works Lab, Creativity studio, Focus studio, Multimedia Techniques Laboratory, Recording studio, Innovation and Technology Transfer Support Lab, Analysis and Simulations Lab, Prototyping Techniques Studio, Technological Innovation Lab. It cooperates with dozens national and international partners and conducts several research projects. All staff members may turn to them for assistance.

The Department of Young Researchers' Innovation Development aims at strengthening young scholars in relation to their development of innovation and entrepreneurship. The department is responsible for the research and development management, technology transfer, stimulating entrepreneurship for the innovative economy, which includes undertaking and monitoring research projects, funded by grants; organization of activities stimulating innovation and entrepreneurship among young researchers; incentivizing interdisciplinary research, development, and search for innovative ideas in the scientific community through cooperation with the academic community (e.g., Scientific Council, Student Representation, and Young Doctors Council).

Innovation Incubator provides facilities for the WUT scholars and students working in the field of academ- 
ic entrepreneurship and innovation, supporting startups, university technology companies (spin off/out), modern forms of entrepreneurship, business clusters, cooperation with the business sector, and international partners. Education Support Department is responsible for the development of education in the scope of academic entrepreneurship, technology transfer, and commercialization through the organization of courses, training, and workshops; the implementation of educational projects devoted to the academic environment of the WUT in terms of academic entrepreneurship, innovation, technology transfer, and commercialization; the co-organization of internships aimed at the academic environment of the university in terms of academic entrepreneurship development, knowledge transfer, and commercialization (WUT, 2018a).

Besides aforementioned entities, there are many more WUT entities supporting academics (WUT, 2018e; f; b). It should be mentioned that, according to the WUT strategy, faculties are also obliged to effectively endorse their staff. All initiatives are clearly presented at the WUT web page (WUT, 2018d) and also employees are informed about learning possibilities during seminars and conferences and directly by their superiors.

The BME, similarly to WUT, is the best technical university in Hungary. It receives more than 10\% of Hungarian applications for studies. Its strategy is related to government objectives and requirements. The mission of the BME is "is to provide differentiated, multilevel quality education and scientific training, built on strong bachelor programmes, carry out research, development and innovation, and employ an academic staff with PhD degrees and above in engineering, natural sciences and certain fields of economics and social sciences" (Máté, 2007).

The BME intends to provide high level of education and training for students and $\mathrm{PhD}$ students and establish excellent conditions for students and employees assisting them in their development and achieving the highest possible qualifications. Cooperation with the economy, other Hungarian universities, and international entities are of the highest priority of BME, which, as a research university, wants to com- bine basic and applied, theoretical, and utilitarian research with education activities. BME takes care of their students, PhD students, and academics. According to BME strategy, "the University is an outstanding base for the education of future scientists." Combining theory and practice in research with education requires employing people with very high qualifications who learn throughout their lives; "properly prepared and capable institution's human resources" are the most important for the BME.

It employs 3000 teachers and researchers, out of 6000 employees, where the group of young scholars (35-40 year old) has just increased. "BME wishes to pay special attention to this group, while also focusing on supporting young lecturers and researchers who are just starting their career and working towards their doctoral degrees". The BME's strategy aims at strengthening the quality of education, among other activities, by "continuously developing the abilities of BME teaching staff."

Career path for researchers are clearly defined. The BME supports young scholars, especially the best ones, who may participate in secondments, count on the university in gaining their academic titles, and participate in wide variety of trainings, international seminars, and conferences. New plant laboratories, new infrastructure and university programs: Demola Programme, Industrial Campus Programme, SME (Small Medium Enterprise) Programme, new training centers, new business incubators, and new advisory services are established for teachers and researchers to help them in their career and development.

\section{Methodology}

The purpose of this study was to explore expectations and attitudes of young-generation employees of the best technical universities in Poland and Hungary, that is, the WUT and BME. Both the universities are located in the countries of the similar level of development, aspiring to the world league of universities. Currently, there is no research addressing Polish and Hungarian technical university employees' needs and perceptions. 
Table 1. Questions regarding university employees' expectations and perception (Source: Authors' own research)

\begin{tabular}{|c|c|}
\hline Questions in the questionnaire & $\begin{array}{c}\text { Type } \\
\text { of the question }\end{array}$ \\
\hline \multirow{2}{*}{\multicolumn{2}{|c|}{$\begin{array}{l}\text { Research question: } \\
\text { What are employees' needs and requirements in terms of lifelong learning process? } \\
\text { Detailed aim: Characteristics of the employee }\end{array}$}} \\
\hline & \\
\hline $\begin{array}{l}\text { Have you ever heard about lifelong learning? } \\
\text { What does it mean in your opinion? }\end{array}$ & Open question \\
\hline Do you learn in your life? What causes you to learn? & Open question \\
\hline $\begin{array}{l}\text { Do you learn things that are important to you? } \\
\text { Do they concern your job or private life? }\end{array}$ & Open question \\
\hline $\begin{array}{l}\text { Do you quickly and easily learn new things? Do you have any learning habits? } \\
\text { Do you know how to learn? }\end{array}$ & Open question \\
\hline Do you take up learning opportunities? & Yes/No \\
\hline Are you in charge of your learning process? & Yes/No \\
\hline $\begin{array}{l}\text { What are your preferences regarding your learning process? In what manner do you prefer } \\
\text { to learn? What are your favorite education forms? What technical support do you need in } \\
\text { the learning process? }\end{array}$ & Open question \\
\hline Do you need a teacher or maybe do you prefer a self-directed learning process? & Open question \\
\hline $\begin{array}{l}\text { What kind of knowledge do you need in the context of private life } \\
\text { and in your job? }\end{array}$ & Open question \\
\hline What skills do you need in the context of private life and in your job? & Open question \\
\hline Can you see any difference between education and learning? & Open question \\
\hline \multicolumn{2}{|l|}{ Detailed aim: Informal education } \\
\hline $\begin{array}{l}\text { What kind of informal (non-formal) learning activities do you take up } \\
\text { or would you like to take up? Do they concern your job or your private life? }\end{array}$ & Open question \\
\hline \multicolumn{2}{|l|}{ Detailed aim: Formal education } \\
\hline $\begin{array}{l}\text { When you choose formal education what are your motives? What is more important for } \\
\text { you: knowledge or diploma or a certificate? } \\
\text { What might possibly help you in your prospective career? } \\
\text { Does formal education concern your job or private life? }\end{array}$ & Open question \\
\hline $\begin{array}{l}\text { What kind of formal learning activities do you take up or would you like to take up? } \\
\text { Do you need them in private life or in your job? }\end{array}$ & Open question \\
\hline \multicolumn{2}{|l|}{ Detailed aim: Perception of the university } \\
\hline $\begin{array}{l}\text { Does the university promote lifelong learning? } \\
\text { What is the role of lifelong learning at the university? }\end{array}$ & Open question \\
\hline $\begin{array}{l}\text { Does the university have a strategy regarding improving employees' qualifications? } \\
\text { Do they express their policy, values or expectations? Do they set any requirements for } \\
\text { employees? Are the employees aware of those rules? Can the employees learn something } \\
\text { else than they are suggested? }\end{array}$ & Open question \\
\hline $\begin{array}{l}\text { Does the university respond to the employees' needs? } \\
\text { Do they endorse lifelong learning in terms of organizational and financial support? }\end{array}$ & Open question \\
\hline $\begin{array}{l}\text { Are there any courses or learning materials available for employees? What kind of life- } \\
\text { long learning opportunities does the university provide for its employees? Are there any } \\
\text { requirements for the employees to take advantage of lifelong learning? Does the universi- } \\
\text { ty provide access to library databases? Are you aware of them? }\end{array}$ & Open question \\
\hline
\end{tabular}


In the study, a qualitative research was performed at the WUT and the BME. As a key method, individual structured interview was applied. Using triangulation method, juxtaposing interviews results with literature review, the aim of the research was to collect employees' opinions and expectations that might be beneficial for the authorities of both universities. The opportunity to compare the best technical universities in very similar countries was also interesting. For this reason, the same set of questions was prepared for both universities based on social research regarding quality of education (Modrzejewska K., Wycisk A., Parzych D., Wycisk A., Pietruszewska A., 2014).

The questions were checked and approved by the authorities of the WUT in terms of the content, form, and ethics. The study was guided by the following research question: What are employees' needs and requirements in terms of lifelong learning? The following aims are taken into account: employees' characteristics, informal education, formal education, and perception of the university. Additionally, respondents were asked about their age and university location. All questions are presented in Table 1.

The employees were interviewed "face to face" or were asked to answer the questions online. Research participants' confidentiality was protected. All interviews were anonymized according to the General Data Protection Regulation Act (Official Journal of the European Union, 2016). The research was based on the population of 37 respondents - young employees representing all departments, generation $\mathrm{Z}$ (GEN-Z, born 1990-2000) and generation Y (GENY, born 1980-1989) - 31 scholars from the WUT and 6 from the BME. The study was performed in April 2018. For data analysis, the inductive research strategy was used; the conclusions were derived based on patterns discerned in the data (Stake R.E., 2010; Brinkmann, 2013). The authors wanted to capture the subjective opinions employees of both the universities.

\section{$4 \quad$ Results and discussion}

The results of the study are presented successively for detailed interviews goals for GEN-Z and GEN-Y employees for both the universities. Characteristics of the employees included their awareness of lifelong learning process, their learning requirements both at work and in private life, and their way of acquiring knowledge, preferred style of learning. Respondents were asked if they take up learning opportunities, if they are responsible for their learning process, and, first of all, if they are eager to learn.

Referring to the employees' knowledge regarding lifelong learning, it turned out that some employees, from both the universities and both the generations, have never heard about it. Even though the term "lifelong learning" is self-explanatory, there are many definitions in the literature. According to Collins English Dictionary, it is "the provision or use of both formal and informal learning opportunities throughout people's lives in order to foster the continuous development and improvement of the knowledge and skills needed for employment and personal fulfillment" (Collins English Dictionary, 2018). Cambridge Dictionary defines this notion as "the process of gaining knowledge and skills throughout your life, often to help you do your job properly" (Cambridge Dictionary, 2018), while Oxford Dictionary specifies it as "a form of or approach to education which promotes the continuation of learning throughout adult life, especially by making educational material and instruction available through libraries, colleges, or information technology" (Oxford Living Dictionaries, 2018).

According to the European Commission, lifelong learning means "the on-going access to the renewing of skills and the acquisition of knowledge" (European Commission, 1995). Not everyone, but most of employees has already known the notion "lifelong learning." The meaning is clear and even those who claim that have never heard about it quoted the proper definition. No significant differences between both universities' representatives and both generations were noticed.

Exemplary opinions are presented in Table 2. Almost everybody said that they use emerging opportunities to learn; moreover, they learn what they want. At both the universities, there is complete freedom of choice; everyone may choose research he/she conducts, learning subjects, and training opportunities. Employees distinguish education from learning. 
Education, in all employees' opinion, is a formal process organized by an institution; connected with teaching, sometimes compulsory; imposed from outside; structured and formal; ending with a diploma or a certificate. On the contrary, learning is a voluntary activity, individual, self-directed, and internal process, which is more interesting. According to respondents' opinions "Learning is a process that aims to acquire knowledge and competences, while education is a system that organizes the learning process," "education does not always lead to learning," and "what is taught should be learnt because otherwise it is lost."

Table 2. Lifelong learning understanding by the WUT and BME employees

(Source: Authors' own research)

\begin{tabular}{|c|c|c|}
\hline & WUT & BME \\
\hline 竞 & $\begin{array}{l}\text { - Lifelong learning is forced by technological pro- } \\
\text { gress, new software, and new procedures. Some- } \\
\text { times it is necessary to learn everything from } \\
\text { scratch, to adapt to continuously changing world. } \\
\text { - Learning throughout whole life, even after finish- } \\
\text { ing formal education. } \\
\text { - Continuous acquisition of knowledge. } \\
\text { - Continuous improvement, raising qualifications } \\
\text { and developing interests. }\end{array}$ & $\begin{array}{l}\text { - Continuously improving knowledge. } \\
\text { - Learning about unknown things. } \\
\text { - Continuously gathering experience. } \\
\text { - Voluntary participating in trainings and courses, } \\
\text { even after graduation. } \\
\text { - Deepening your knowledge. Gathering experi- } \\
\text { ences that are unique and unrepeatable, and each } \\
\text { contributes to life in a different way, enriching } \\
\text { it (with different lessons). Thus, you continue } \\
\text { learning about life until the end of your life. }\end{array}$ \\
\hline 齐 & $\begin{array}{l}\text { - Learning all the time, even after graduation, up- } \\
\text { dating knowledge during formal trainings and } \\
\text { courses as well as on your own. } \\
\text { - Deepening skills and knowledge throughout } \\
\text { whole life. } \\
\text { - An approach to life consisting in constant devel- } \\
\text { opment (getting to know/learning new things). } \\
\text { - Do not expect that school will provide you all } \\
\text { required knowledge, you have to learn constant- } \\
\text { ly. } \\
\text { - Continuous acquisition and development } \\
\text { of knowledge. }\end{array}$ & $\begin{array}{l}\text { - Continuous self-instruction after finishing uni- } \\
\text { versity studies (courses, videos, conferences, } \\
\text { books). } \\
\text { - Learning all the time in order to cope with } \\
\text { changing world. } \\
\text { - Continuous learning. } \\
\text { - Process that preserve mental freshness and im- } \\
\text { proves the position in the labor market. }\end{array}$ \\
\hline
\end{tabular}

Taking into account the subject of learning (considering private life and work) and reasons for learning, there were no significant differences among the WUT and BME employees and among representatives of GEN-Z and GEN-Y. Respondents' opinions are presented in Table 3.

Everybody is interested in learning subjects regarding scientific research and conducted lectures. Knowledge about research is put first. The most frequently indicated topics regarding research are statistics; mathematical modeling; data analysis; data visualization; preparing scientific presentations; searching for information; proficiency in languages, especially writing scientific articles and speaking in English; writing project proposals; and vocational knowledge. Second important, in order, is lecturing.
Besides research, this is the most common subject of self-learning. Employees, both from the WUT and BME, want to prepare their lectures perfectly. They spend dozens of hours to improve pedagogical skills and prepare their classes. Representatives of GEN-Y consider conducting diploma theses as important and requiring preparation and learning. It is understandable because only $\mathrm{PhDs}$ may take care of students who write diploma theses; representatives of GEN-Z are too young to recall this argument. And last but not least, soft skills are quoted.

Presentations skills, communication, social skills, establishing contacts, socializing, networking, cooperation, and conflict management are very important for everyone. Also personal soft skills are valued. 
Table 3. Subject and reasons for learning in work and private life of the WUT and BME employees (Source: Authors' own research)

\begin{tabular}{|c|c|c|c|c|c|}
\hline \multirow{2}{*}{ 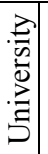 } & \multirow{2}{*}{ 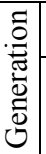 } & \multicolumn{2}{|c|}{ Subject of learning } & \multicolumn{2}{|c|}{ Reasons for learning } \\
\hline & & Professional work & Private life & Professional work & Private life \\
\hline & $\frac{N}{Z_{0}}$ & $\begin{array}{l}\text { - Topics regarding research - research } \\
\text { methods; } \\
\text { - Vocational knowledge; } \\
\text { - Writing project proposals; } \\
\text { - Statistics; } \\
\text { - Foreign languages; } \\
\text { - Writing in English; } \\
\text { - Programming; } \\
\text { - Analytical thinking; } \\
\text { - Searching for information; } \\
\text { - Pedagogical knowledge; } \\
\text { - Communication skills; } \\
\text { - Learning skills. }\end{array}$ & $\begin{array}{l}\text { - Raising children; } \\
\text { - Cooking; } \\
\text { - Running household; } \\
\text { - Sports; } \\
\text { - Religions; } \\
\text { - Time (self) manage- } \\
\text { ment; } \\
\text { - Social skills: under- } \\
\text { standing others, soci- } \\
\text { ology, psychology, } \\
\text { assertiveness, creativi- } \\
\text { ty, communication } \\
\text { skills. }\end{array}$ & $\begin{array}{l}\text { - Development; } \\
\text { - Being attractive at } \\
\text { the labor market; } \\
\text { - Earnings; } \\
\text { - New challenges at } \\
\text { work. }\end{array}$ & $\begin{array}{l}\text { - Widespread inter- } \\
\text { ests; } \\
\text { - Desire to expand } \\
\text { knowledge; } \\
\text { - Self-development; } \\
\text { - Curiosity; } \\
\text { - Need of change; } \\
\text { - Hobby. }\end{array}$ \\
\hline$\stackrel{-}{\lessgtr}$ & $\frac{7}{Z_{0}^{\prime}}$ & $\begin{array}{l}\text { - Research topics; } \\
\text { - Writing scientific articles; } \\
\text { - Learning new issues regarding scien- } \\
\text { tific work; } \\
\text { - New software; } \\
\text { - Programming; } \\
\text { - Data analysis; } \\
\text { - Big Data; } \\
\text { - Deep learning; } \\
\text { - New theoretical tools; } \\
\text { - Mathematical modeling; } \\
\text { - Digital technologies; } \\
\text { - Lecture topics; } \\
\text { - Diploma theses topics; } \\
\text { - Issued related to university organiza- } \\
\text { tional work; } \\
\text { - Project management; } \\
\text { - Soft skills: writing and speaking both } \\
\text { in Polish and English, quick learning, } \\
\text { public presentations; efficient and } \\
\text { elegant writing, communication, self } \\
\text { management, organiza-tion of work- } \\
\text { ing time, decision making, socializ- } \\
\text { ing, networking, conflict } \\
\text { management; negotiations. }\end{array}$ & $\begin{array}{l}\text { - Raising children; } \\
\text { - Languages; } \\
\text { - Photography; } \\
\text { - Travels; } \\
\text { - „Do It Yourself” abili- } \\
\text { ties; } \\
\text { - Maintaining the quali- } \\
\text { ty of family life; } \\
\text { - Financial manage- } \\
\text { ment; } \\
\text { - Foundations of medi- } \\
\text { cine; } \\
\text { - History; } \\
\text { - Art; } \\
\text { - History of art; } \\
\text { - Philosophy; } \\
\text { - Social processes. }\end{array}$ & $\begin{array}{l}\text { - Acquiring new, } \\
\text { and deepening } \\
\text { knowledge; } \\
\text { - Improvement at } \\
\text { work; } \\
\text { - Finishing PhD } \\
\text { thesis; } \\
\text { - Maintaining quali- } \\
\text { fication; } \\
\text { - Benefits; } \\
\text { - Learning new } \\
\text { technologies; } \\
\text { - Conducting di- } \\
\text { ploma theses; } \\
\text { - Logical thinking; } \\
\text { - Making quick } \\
\text { decisions. }\end{array}$ & $\begin{array}{l}\text { - Children; } \\
\text { - Curiosity; } \\
\text { - Communication in } \\
\text { foreign countries; } \\
\text { - Developing own } \\
\text { interests; } \\
\text { - Expanding hori- } \\
\text { zons; } \\
\text { - Acquiring new } \\
\text { skills; } \\
\text { - Natural inclination } \\
\text { to learning; } \\
\text { - Awareness of own } \\
\text { imperfection; } \\
\text { - Keeping in touch } \\
\text { with people; } \\
\text { - Self management; } \\
\text { - Acquiring soft } \\
\text { skills-Adding } \\
\text { value to life; } \\
\text { - Boredom. }\end{array}$ \\
\hline \multirow[t]{2}{*}{$\sum_{m}^{\infty}$} & $\frac{N}{Z}$ & $\begin{array}{l}\text { - Research topics; } \\
\text { - Languages; } \\
\text { - Searching for information; } \\
\text { - Soft skills: presentation and commu- } \\
\text { nication skills, evaluating others, cre- } \\
\text { ativity, establishing contacts with } \\
\text { others, discipline, being focused, per- } \\
\text { sistence. }\end{array}$ & $\begin{array}{l}\text { - Raising Children; } \\
\text { - Cooking; } \\
\text { - Psychology; } \\
\text { - Management; } \\
\text { - Languages; } \\
\text { - Patience; } \\
\text { - Humility; } \\
\text { - Conflict management; } \\
\text { - Music, dance, and art. }\end{array}$ & $\begin{array}{l}\text { - Prospect work as a } \\
\text { lecture; } \\
\text { - Inspiring and } \\
\text { influencing others; } \\
\text { - Desire to acquire } \\
\text { knowledge. }\end{array}$ & $\begin{array}{l}\text { - Learning as a way } \\
\text { to grow up; } \\
\text { - Learning as a way } \\
\text { to become better } \\
\text { member of the } \\
\text { society; } \\
\text { - Enjoying learning. }\end{array}$ \\
\hline & $\frac{7}{\frac{1}{Z}}$ & $\begin{array}{l}\text { - Research topics; } \\
\text { - Lecture topics; } \\
\text { - Theory and practice required at work; } \\
\text { - Data visualization; } \\
\text { - Soft skills: presentation techniques, } \\
\text { communication, cooperation, speak- } \\
\text { ing skills, appearance. }\end{array}$ & $\begin{array}{l}\text { - Creativity, communi- } \\
\text { cation skills, } \\
\text { - Proactive attitudes, } \\
\text { consciousness, and } \\
\text { practical knowledge. }\end{array}$ & $\begin{array}{l}\text { - Professional de- } \\
\text { velopment; } \\
\text { - Technological } \\
\text { requirements; } \\
\text { - Benefits. }\end{array}$ & $\begin{array}{l}\text { - Curiosity; } \\
\text { - Self development; } \\
\text { - Enjoying learning; } \\
\text { - Humility; } \\
\text { - Mercy for others } \\
\text { and myself. }\end{array}$ \\
\hline
\end{tabular}


The following skills are also cited: good appearance; ability to speak somebody's mind; ability to concentrate; discipline; persistence; humility; time management; good self-organization; quick learning; efficient and elegant writing, especially in English; ability to learn; and analytical thinking.

Private life skills are as important as work knowledge. GEN-Z members quote raising children; running household; cooking; learning languages; doing sports; communicating with others, especially with in-laws; understanding others; assertiveness; and conflict management abilities.

Foundations of managements, psychology, and sociology are eagerly learned. GENZs add to aforementioned topics maintaining the quality of family life and learning new things such as economics and finance for home purposes and new languages, for example, Norwegian, philosophy, foundations of medicine, history, music, dance, art, history of art.

An engineer said "Humanistic knowledge - philosophical, historical, art history - allow you to look at the world in the right perspective and give life value." For GEN-Y, family is very important; however, they do not want to give up work. They are frequently about to finish their $\mathrm{PhD}$ theses and have no time at all. One person is wondering "How to feed a small child when it does not want to eat, and the two older ones pull the sleeve. How to maintain romanticism in married life, while you are overloaded with professional work."

All employees like learning and they want to expand their knowledge, sometimes for the art's sake. Children, curiosity, desire for development, expanding horizons, acquiring new skills, need of change, hobby, and boredom are private reasons for learning. GEN-Zs treat learning like a way for growing up, a method for becoming a valuable member of society. GEN-Ys underline finishing $\mathrm{PhD}$ theses, maintaining qualifications, and professional development. Everybody wants to be attractive at the labor market and enjoy taking up new challenges at work. Everyone underlines that earnings and benefits are very important; however, university job is unstable and wages are very low.

Nearly all employees take up formal and informal training. The main subject of informal education is learning languages. Everyone admits that they used to learn or actually learn languages in private lessons, at private schools, via Skype, using YouTube, or Moocs. EdX, Open University, Khan Academy, and Coursera are predominantly recalled. Internet tutorials, seminars, conferences, and discussions with experts are hugely popular. It is interesting that everyone learns topics connected with university work during informal learning.

Both university employees and representatives of both generations devote their private time and energy to develop their knowledge and skills in order to be better and better at work. Also all employees participate in formal education. The main courses taken by respondents are $\mathrm{PhD}$ studies. Anyone who wants to be promoted at the university must hold a doctorate degree. Besides $\mathrm{PhD}$ training, employees take up postgraduate studies and various courses and trainings. In this case, employees also tell about studies and courses at regular universities and using online methods. Polish GEN-Ys underline reliability of formal education. Hungarian GEN-Zs feel more valuable while attending formal education.

One of the Polish GEN-Y employees said „I myself organize courses, for example with writers, to learn to write, with painters, to learn to see, with actors, to better lecture, with coaches, to better manage my time and energy. I also initiate meetings with mentors to concentrate on scientific work on important matters." Everyone emphasizes importance of diplomas and certificates. Employment systems at public universities, both in Poland and in Hungary, require collecting lots of certificates, starting from $\mathrm{PhD}$ diploma ending with documenting every citation.

The research showed no significant differences in lifelong learning understanding. The overall characteristics of the GEN-Z and GEN-Y employees are very similar. Also there are no significant differences among representatives of the WUT and the BME scholars. The study draws attention to employees' perception of their universities. Vast majority of employees do not know if their university has any lifelong learning strategy and if it responds to its staff expectations. Only one person, GEN-Z representative from the WUT has heard about any strategy, but nothing specific. GEN-Ys have mentioned 
some language and soft skills courses, however, not tailored for academics' requirements. In GEN-Ys' opinion, the strategy is a result of the Act for Higher Education and requirements of acquiring academic degrees. An employee has 8 years for finishing a doctoral degree and another 8 years for habilitation. In the WUT respondents' point of view, this is the only strategy of the university.

Some academics underline that "any development results from the individual needs of the employee and is independently financed and initiated by him/her." Another person claims that the strategy "results from higher education system requirements and conducting scientific research." WUT trainings and courses, if offered in the first place, are very general and not customized to employees' needs.

Most of the GEN-Ys do not know about any courses; the ones that do and attend them are not satisfied. GEN-Zs also do not know anything about the courses offered by the WUT. Sometimes they receive emails about new courses; however, they are not interesting to them. PhD students, who teach and conduct scientific research and treated almost like employees, complain that courses offered by the WUT are only for employees and they cannot attend. The WUT employees claim the university has no strategy regarding improving their qualifications. There is no systemic thinking and no career planning. Employees feel uninformed.

According to the WUT employees' opinion, the university does not provide any support and does not respond to their needs. Courses regarding soft skills and computer training are not sufficient to develop academics. On the other hand, the WUT scholars say that they may participate in conferences, they can pay for their courses and postgraduate studies from statutory grants, and they can rely on their $\mathrm{PhD}$ theses supervisors who help them in everything.

GEN-Ys learn while conducting scientific research in outstanding research teams, they participate in many courses regarding research and their teaching areas, and they have to implement what they have learnt. Employees emphasize the importance of the WUT library and rich databases; however, they regret that there are fewer and fewer of them.
The BME employees do not know anything about the university lifelong learning strategy. One person (GEN-Z representative) thinks that the strategy is an obligation of publishing scientific articles. GEN-Ys no not know anything about any courses offered by the university, while GEN-Zs claim that the BME has a strategy in which they can travel abroad, participate in scientific conferences, and the university covers all costs. Unfortunately, almost no one heard about library databases. Only one GEN-Y person knows the library offer.

\section{Summary}

The current research was undertaken because the WUT and the BME are the best technical universities, respectively, in Poland and in Hungary and both seek for better positions in the world university rankings. Universities achievements depend on the quality of their staff. Even though the universities offer a large amount of development possibilities for scholars, the effects might be different from anticipated. The study was expected to shine more light on scholars' opinions and requirements and their awareness of possibilities offered by the universities.

All respondents understand the difference between education and learning. In their opinion, education is a formal process, while learning is self-directed. Learning means freedom to make a decision what to learn; on the contrary; in education; the system decides about what is taught and what one should learn. Learning means knowledge; education means also upbringing (Polish response). Employees from both countries understand that informal learning means learning outside the formal system. They recall the examples of learning from peers, learning languages, learning from experience, talking with experts, seminars, professional fairs, private trainings, and online learning.

Many employees would like to take up new courses; however, they cannot afford it. The salaries of academic staff are too low to allow for additional learning. Employees also would like to take up formal courses, for example, postgraduate studies, regarding both work and private interests, juxtaposing theory and practice, organized in the form of projects, in small groups (Polish GEN-Ys' opinions). GEN-Zs 
prefer online training, for example, Moocs, courses they could take up whenever they want. Both Polish and Hungarian GEN-Z employees consider learning languages as the most important. They would like to attend good language courses because they need proficiency in English.

Employees from both countries agree that formal education and diplomas are compulsory at the universities. Knowledge is very important to them; nonetheless, they take up doctoral and postgraduate studies to be promoted. Formal courses and trainings sometimes are assessed poorly because of excess of theory and lack of practical knowledge. Courses, especially those financed from the EU funds, are not devoted to the employees' needs (Polish response). According to the employees, teachers and coaches are not good enough for young researchers. They do not keep up with the employees' way of thinking (Polish response).

Everyone is aware of the necessity of learning at the university. GEN-Z representatives are in their $\mathrm{PhD}$ processes, and their aim is to finalize the procedure. GEN-Y employees already have PhDs and they would like to achieve next academic title - habilitation. None of them state that they are know-it-all persons. They would like to learn, even take up postgraduate studies, but after the habilitation. GEN-Zs (from the WUT) underline that learning is for everyone and at any age, not only at school. All respondents state that learning is part of their life.

Both Polish and Hungarian GEN-Zs are curious and eager to develop because they want to become lecturers. GEN-Y employees are already lecturers and their motivation is to keep up with other colleagues, both from their university and from abroad. GEN-Zs want to learn languages while GEN-Ys want to learn technical skills important in their work; they claim that they already know languages. They even learn second or the third language such as French (Hungarian response) or Norwegian (Polish response).

All respondents are interested in sports, healthy cuisine, and raising children. GEN-Ys have more additional interests, for example, history of church, photography, and do-it-yourself activities; however, they state that they need time management skills in order to take care of all activities. Everyone needs social skills, that is, communication skills, selfdiscipline, assertiveness, creativity, presentation skills, public speaking, professional writing, openness, curiosity, patience, conflict management, group work, psychology, and sociology. In regard to skills required at work, both GEN-Zs and GEN-Ys from both the universities need predominantly statistical data analysis and mathematical modeling and also analytical thinking, programming, new tools regarding their subject of work. All of them need technical knowledge regarding preparing presentations, teaching students, fast learning skills, and logical thinking. Most employees claim that they decide what they learn and undertake learning opportunities. Only a few people state that the university decides what knowledge they need. Some of the GEN-Z employees have problems with learning process. Some of them have problems with concentration (Hungarian response: "I have problems with sitting in one place and reading 200 pages," Polish response: "I need peace and quiet"; however, some respondents, both Hungarian and Polish, say that they know how to learn but nobody told them how to do it. They do not know their learning preferences.

People from both universities indicate that videos, TED, YouTube, and Moocs courses (EdX, Coursera) are the best learning methods. They may learn what they want and anytime they want. What is interesting is both Hungarians and Polish GEN-Zs and GEN-Ys consider teaching others as the best learning method. All of them prefer practical to theoretical learning. GEN-Y staff also reads a lot and takes notes. All of them emphasize that regularity and repetition are very important.

Employees from both the countries strictly evaluate their universities. Respondents claim that teaching new courses and conducting research means learning all the time. Employees are evaluated by students and by supervisors, and if they want to stay at work, they must learn (Hungarian response). In Poland, an employee has 8 years to prepare $\mathrm{PhD}$ thesis and another 8 years to get habilitation. If they do not meet these requirements, they would be dismissed (Polish response). In Poland, universities assign too much work to workers leaving no time for learning 
and development. On the contrary, in Hungary, one has $20 \%$ of their working time for own work.

Employees do not know if universities have employee development programs and HR strategy. There are no funds for trainings that employees need, and courses organized by the university are too general and nonspecific. Despite of those opinions, some employees claim that the universities have HR strategy, have money for conferences and training, and even cover training fees and travel costs when those events are abroad (Hungarian response).

We hope that the presented study will be noticed by the universities' authorities. Motivated and welleducated employees will repay the universities with better research and educational results. In order to achieve those goals, universities should listen to their employees, encourage them to learn, and support them. Employees want to know what is going to happen in the future. The earnings are also very important; they do not really depend on the universities; however, the best people should be appreciated and noticed. Presented findings were prepared based on the qualitative research. In order to confirm and validate the results, a quantitative research might be prepared and conducted.

\section{References}

[1] Brinkmann, S., 2013. Qualitative Interviewing. Cary, UNITED STATES: Oxford University Press, Incorporated.

[2] Cambridge Dictionary, 2018. lifelong learning Meaning in the Cambridge English Dictionary. [online] Available at: <https://dictionary. cambridge.org/dictionary/english/lifelonglearning $>$ [Accessed 9 Aug. 2018].

[3] Collins English Dictionary, 2018. Lifelong learning definition and meaning | Collins English Dictionary. [online] HarperCollins Publishers. Available at: <https://www.collins dictionary.com/dictionary/english/lifelonglearning $>$ [Accessed 1 May 2018].

[4] Council of the European Union, 2002. Declaration of the European Ministers of Vocational Education and Training, and the European Commission, convened in Copenhagen on 29 and 30 November 2002, on enhanced European cooperation in vocational education and training \&quot;The Copenhagen
Declarat. Available at: <https://europass. cedefop.europa.eu/sites/default/files/copenhagen -en.pdf $>$ [Accessed 18 Aug. 2018].

[5] Council of the European Union, 2018. COUNCIL RECOMMENDATION of 22 May 2018 on Key Competences for Lifelong Learning. [online] Brussels. Available at: $<$ https://eur-lex.europa.eu/legalcontent/EN/TXT/PDF/?uri=CONSIL:ST 9009 2018 INIT\& from $=E N>$ [Accessed $2 \overline{5}$ Aug. 2018].

[6] European Commission, 1995. TEACHING AND LEARNING TOWARDS THE LEARNING SOCIET. [online] Brussels. Available at: $<$ http://eur-lex.europa.eu/legal-

content/EN/TXT/PDF/?uri=CELEX:51995DC05 90\&from $=\mathrm{EN}>$ [Accessed 1 May 2018].

[7] European Commission, 2006. Council Recommendation on Key Competences for Lifelong Learning - European Commission. [online] Available at: <https://ec.europa.eu/ education/initiatives/european-education-area/ proposal-council-recommendation-key-compe tences-lifelong-learning_en> [Accessed 25 Aug. 2018].

[8] European Commission, 2018a. Education and Training Monitor: Interactive maps - European Commission. [online] Available at: $<$ http://ec.europa.eu/education/policy/strategicframework/dashboard> [Accessed 25 Aug. 2018].

[9] European Commission, 2018b. Education and Training Monitor 2017. [online] Brussels. Available at: $<$ http://ec.europa.eu/education /sites/education/files/monitor2017_en.pdfs [Accessed 19 Aug. 2018].

[10] European Commission, 2018c. Education and Training Monitor 2017 Hungary. [online] Brussels. Available at: <http://europa.eu> [Accessed 17 Aug. 2018].

[11] European Commission, 2018d. Education and Training Monitor 2017 Poland. Brussels.

[12] European Commission, 2018e. IMPROVING 8 KEY COMPETENCES. [online] Brussels. Available at: <https://ec.europa.eu/education/ sites/education/files/factsheet-recommendationkey-competences-lifelong-learning.pdf $>$ [Accessed 25 Aug. 2018].

[13] European Commission, 2018f. Key competences - European Commission. [online] Available at: $<$ http://ec.europa.eu/education/policy/school/co mpetences_en $>$ [Accessed 25 Aug. 2018].

[14] European Commission, 2018g. The European Pillar of Social Rights in 20 principles 
European Commission. [online] Available at: $<$ https://ec.europa.eu/commission/priorities/deep er-and-fairer-economic-and-monetaryunion/european-pillar-social-rights/europeanpillar-social-rights-20-principles_en $>$ [Accessed 25 Aug. 2018].

[15] European Social Fund, 2013. Human Capital Investment Operational Programme.

[16] Eurostat, 2018. Adult learning statistics Statistics Explained. [online] Available at: $<$ http://ec.europa.eu/eurostat/statistics-explained /index.php?title=Adult_learning_statistics $>$ [Accessed 18 Aug. 2018].

[17] EURYDICE, 2018. Adult Education and Training in Hungary| Eurydice. [online] Available at: <https://eacea.ec.europa.eu/natio nal-policies/eurydice/content/adult-educationand-training-35_en $>$ [Accessed 25 Aug. 2018].

[18] Faure Edgar, Herrera Felipe, Kaddoura AbdulRazzak, Lopes Henri, Petrovsky Arthur V., Rahnema Majid, W.F.C., 1972. Learning to be. [online] Paris. Available at: $<$ http://www.unesco. org/education/pdf/15_60.pdf $>$ [Accessed 2 May 2018].

[19] Janne, H., 1973. Bulletin of the European Communities Supplement $10 / 73$ For a Community policy on education. [online] Brussels. Available at: $<$ http://aei.pitt.edu/5588 /1/5588.pdf $>$ [Accessed 18 Aug. 2018].

[20] Kobylarek, A., 2002. Edukacja wobec barier rozwoju społeczeństwa transformacyjnego. Edukacja dorostych, [online] 4, pp.31-42. Available at: <https://www.researchgate.net/ publication/271908414> [Accessed 19 Aug. 2018].

[21] Máté, S., 2007. Budapest University of Technology and Economics. [online] Available at: <https://www.bme.hu/sites/default/files/csato lmanyok/bme_angol_ift.pdf $>$ [Accessed 10 Aug. 2018].

[22] Modrzejewska K., Wycisk A., Parzych D., Wycisk A., Pietruszewska A., M.D., 2014. Badania społeczne $w$ zakresie jakości kształcenia na Politechnice Warszawskiej. Warszawa: Politechnika Warszawska-Biuro Rozwoju i Projektów Strategicznych.

[23] Official Journal of the European Communities, 2002. COUNCIL RESOLUTION of 27 June 2002 on lifelong learning (2002/C 163/01). Available at: <https://eur-lex.europa.eu/Lex
UriServ/LexUriServ.do?uri=OJ:C:2002:163:000 1:0003:EN:PDF> [Accessed 18 Aug. 2018].

[24] Official Journal of the European Union, 2016. General Data Protection Regulation, (EU) 2016/679. [online] Brussels. Available at: $<$ https://eur-lex.europa.eu/legal-content/EN/ TXT/PDF/?uri=CELEX:32016R0679\&from $=\mathrm{E}$ $\mathrm{N}>$ [Accessed 28 Aug. 2018].

[25] Oxford Living Dictionaries, 2018. Definition of lifelong learning in English by Oxford Dictionaries. [online] Available at: $<$ https://en.oxforddictionaries.com/definition/life long_learning $>$ [Accessed 1 May 2018].

[26] Stake R.E., 2010. A qualitative case study. In: L.Y.S. Denzin N. K., ed., Methods of qualitative research. Warszawa: Wydawnictwo Naukowe PWN, pp.632-633.

[27] Warsaw University of Technology, 2011. Warsaw University of Technology 2020 Development Strategy. [online] Warsaw. Available at: $<$ https://www.bip.pw.edu.pl/var/pw /storage/original/application/1ae2c2a83dcba19b 59041610b668a1f1.pdf $>$ [Accessed 10 Aug. 2018].

[28] WUT, 2018a. Center for Innovations and Technology Transfer Management. [online] Available at: <https://www.cziitt.pw.edu.pl/> [Accessed 26 Aug. 2018].

[29] WUT, 2018b. Project NERW - Knowledge, Education, Development and Cooperation. [online] Available at: <https://www.nerw. pw.edu.pl/> [Accessed 26 Aug. 2018].

[30] WUT, 2018c. Warsaw University of Technology, Training Department. [online] Available at: $<$ https://www.szkolenia.pw.edu.pl/O-nas $>$ [Accessed 26 Aug. 2018].

[31] WUT, 2018d. Warsaw University of Technology Web Page. [online] Available at: <https:// www.pw.edu.pl/engpw $>$ [Accessed 26 Aug. 2018].

[32] WUT, 2018e. WUT Project Management Office. [online] Available at: <https://www.cop. pw.edu.pl $/>$ [Accessed 26 Aug. 2018].

[33] WUT, 2018f. WUT Research Centers. [online] Available at: $<$ https://www.pw.edu.pl/Badania-inauka/Centra-Badawcze $>$ [Accessed 26 Aug. 2018]. 